\title{
Weekly Rainfall Analysis for Crop Planning in Junagadh District of Gujarat, India
}

\author{
Pappu Kumar Paswan ${ }^{1}$, G. R. Sharma ${ }^{2}$, Abhishek Pratap Singh ${ }^{3}$ and M. D. Ojha ${ }^{4^{*}}$ \\ ${ }^{1}$ Department of Soil and Water Conservation Engineering, College of Agricultural \\ Engineering and Technology, Junagadh Agricultural University, \\ Junagadh, 362001, Gujarat, India \\ ${ }^{2}$ Department of Soil and Water Conservation Engineering, College of Agricultural \\ Engineering and Technology, Polytechnic in Agricultural Engineering, \\ Junagadh Agricultural University, Targhadia, Rajkot, Gujarat, India \\ ${ }^{3}$ Krishi Vigyan Kendra, Purnea, BAU, Sabour, India \\ ${ }^{4}$ Nalanda College of Horticulture, Noorsarai, Nalanda, BAU, Sabour, India
}

*Corresponding author

\section{A B S T R A C T}

Keywords

Weekly Rainfall, Probability distribution, Water balance, Crop Planning

Article Info

Accepted: 05 April 2020 Available Online: 10 May 2020

\begin{abstract}
The historical rainfall data for the period of 37 years (1981-2017) of Junagadh district in Gujarat were analyzed for selection of most appropriate probability distribution of rainfall. From the analysis, it was found that one single probability distribution has not been found appropriate to represent all the data sets though Gamma distributions, Gumbel max.distribution and generalized extreme value distribution were found promising for most of the data sets. The best-fit distribution has been employed for obtaining the assured quantum of rainfall pertaining to23-42 Standard Meteorological Weeks (SMW) at various probability levels. The minimum assured rainfall of $20 \mathrm{~mm}$ and more are expected from SMW 27 onwards at $70 \%$ probability. This indicated that the sowing of kharif crops has to be done during the 27 SMW for maximum utilization of rain water. Weekly reference evapotranspiration values were estimated by the Penmen Monteith method. Water balance study by Thornthwaite and Mather. Revealed that water deficit was found to be $51.40 \mathrm{~mm}$ in driest year and maximum water surplus was $42.80 \mathrm{~mm}$. Crop water requirement of groundnut (bunch and spreading), cotton and wheat are $338.63 \mathrm{~mm}, 414.08 \mathrm{~mm}, 818.42 \mathrm{~mm}$ and $581.28 \mathrm{~mm}$ respectively. Based on the analysis, crop planning in Junagadh district of Gujarat is suggested.
\end{abstract}

\section{Introduction}

Rainfed agriculture is practiced under a wide variety of soil type, agro climate and rainfall condition ranging from $400 \mathrm{~mm}$ to $1600 \mathrm{~mm}$ per annum. Agriculture in rainfed region is characterized with risk and uncertainty.
Inadequate rainfall and its uneven distribution along with frequent drought are the common features of rainfed regions. Saurashtra region falls under semi-arid and arid types with varying climatic as well as soil features and issues thereof have been: About 70 per cent of total area is rainfed and there is a wide 
variability in crop yields due to erratic and scanty rainfall. Low soil organic carbon status due to low rainfall and high temperature with minimum recycling of organic residues. The economy is mainly based on the activities related to cotton and groundnut in crop sector and livestock and fisheries in the non-crop sector. In Saurashtra, irrigated area is quite low and most of the irrigation is through open well/tube well which largely depend on monsoon performance. However, due to use of water conservation technologies viz., check dam, bori-bandh, khet-talavdi etc. has reduced the ground water depletion and increase irrigated Rabi area. Besides availability of Narmada canal water has also increased irrigated area. As the water requirement of the crops is very high, scanty rainfall and the less number of rainy days are the difficulty for crop production in the region. Water deficit is a complex and non-linear phenomenon because it depends on several interacting climatologic factors such as precipitation, temperature, humidity, wind speed, bright sunshine hours, etc. Information of the period during which deficiency of moisture in soil are likely to occur is essential so that advance action can be taken to avoid severe moisture stress to the crops. Choice of crop varieties with standing moisture stress, adoption of appropriate conservation measures and life saving irrigation through recycling surplus water may be possible measures by the advance information.

Weekly, monthly and seasonal probability analysis of rainfall data for crop planning has been attempted (Sharma and Thakur, 1995). Weekly distribution of rainfall and its probability is helpful in crop planning by identifying the period of drought, normal and excess rainfall (Ray et al., 1987). Twoparameter probability distributions (normal, lognormal, Weibull, logistic, log-logistic, smallest and largest extreme value), and three-parameter probability distributions (log- normal, gamma, Weibull, and log-logistic) have been widely used for studying flood frequency (Ashkar and Mahdi, 2003; Clarke, 2003) and drought analysis (Quiring and Papakryiakou, 2003; Alam et al., 2014). The task of monitoring and controlling the field water balance is valuable for the efficient management of water and soil.

They computed water surplus, water deficit and actual evapotranspiration by utilizing the precipitation and temperature data. Such information is required for the assessment of long term needs for supplemental irrigation, drainage and water utilization, for the establishment of certain soil-moisture-plant relationships, for the determination of optimum crop management practices and for the proper evaluation of field experiments affected by soil moisture conditions. The effective use of water both in irrigated and rainfed area for crop production is essential. The exact amount of water and correct timing of application is very essential for scheduling irrigations to meet the crop's water demands and for optimum crop production.

The irrigation scheduling based on crop water requirement $\left(\mathrm{ET}_{\mathrm{c}}\right)$ determined by multiplying crop coefficient $\left(\mathrm{K}_{\mathrm{c}}\right)$ values with reference evapotranspiration $\left(\mathrm{ET}_{\mathrm{o}}\right)$, is one of the widely used method (Doorenbos and Pruitt 1975).Rainfall analysis is important in view of crop planning for any region. Rainfall studies, particularly its variability and trend analysis can give more information for rainfed region crop planning. The knowledge of total rainfall and its distribution throughout the year is extremely useful and important for better planning of cropping pattern, developing irrigation and drainage plans for an area. In rainfed agriculture, the total amount of rainfall and its distribution affects the plant growth (Sharma et al., 1979). The philosophy of dry land agriculture revolves around the principle that water in these areas 
being scarce and one has to maximize the use of rain water for agricultural production. The strategy for this agriculture is to narrow down the inter-annual variation, stabilize outturns in favourable years to build up buffer stock. Research therefore, should be directed to evolve means to face variety of conditions, arising out of abnormal weather. The present study "Weekly Rainfall Analysis for Crop Planning in Junagadh District of Gujarat." is a modest attempt to analyze the behaviour of rainfall for Junagadh District of Gujarat.

\section{Materials and Methods}

\section{Description of the problem area}

The present study is based on a time series daily rainfall data of 37 years (1981-2017) observed at Junagadh located in Gujarat State of India. Geographically Junagadh is situated at $21.52^{\circ} \mathrm{N}$ latitude and $70.47^{\circ} \mathrm{E}$ longitude with an elevation of $107 \mathrm{~m}$ above M.S.L. Junagadh faces adverse climatic conditions in summer months with temperature ranging from $28^{\circ} \mathrm{C}$ to $38^{\circ} \mathrm{C}$. In the winter months, temperature ranges from $10^{0} \mathrm{C}$ to $25^{\circ} \mathrm{C}$. The average rainfall is $900 \mathrm{~mm}$. various factors such as its proximity to the sea influence the weather of Junagadh. The latent winds from sea affect the climatic conditions in the region. Highest rainfall $(2800 \mathrm{~mm})$ in a year was recorded in 1983. The rainfall in this region mostly starts from $23^{\text {rd }} \mathrm{SMW}$ with total duration of 20 weeks till $42^{\text {nd }}$ SMW. Thereafter rainfall amount is meagre for rest of the SMW. Therefore the period from $23^{\text {rd }}$ to $43^{\text {rd }}$ SMW is considered for rainfall analysis. Therefore the period from $23^{\text {rd }}$ to $43^{\text {rd }} \mathrm{SMW}$ is considered for rainfall analysis. The climate of the area is semi-arid type having 'average pan evaporation of $6.41 \mathrm{~mm} /$ day. For the country as whole, mean monthly rainfall during July $(286.5 \mathrm{~mm})$ is highest and contributes about $24.2 \%$ of mean annual rainfall $(1182.8 \mathrm{~mm})$.

\section{Statistical analysis}

The descriptive statistics of the weekly rainfall data set was computed i.e. the mean, standard deviation, skewness coefficient and coefficient of variation, minimum and maximum weekly value. The standard deviation will indicate about the fluctuation of the rainfall. The coefficient of skewness was computed for rainfall which explains about the shape of the curve. The coefficient of variation was computed for rainfall which explains the variability in the rainfall data.

\section{Fitting the probability distribution}

To know the rainfall pattern of an area, probability distributions of rainfall are widely used. The present study was planned to identify the best fit probability distribution based on distribution pattern for data set. The different probability distributions were identified out of large number of commonly used probability distributions for such type of study. The probability distributions Viz, Lognormal, Gamma, Inverse Gaussian, Generalized Extreme Value, Weibull, and Gumbel maximum was fitted to the data for evaluating the best fit probability distribution for rainfall data. The description of various probabilities distribution is given in Table 1.

\section{Testing the goodness of fit}

The goodness of fit test measures the compatibility of random sample with the theoretical probability distribution. The goodness of fit tests were applied for testing the following null hypothesis:

$\mathrm{H}_{\mathrm{O}}$ : the weather parameter data follow the specified distribution

$\mathrm{H}_{\mathrm{A}}$ : the weather parameter data does not follow the specified distribution. 
The following goodness of fit tests viz. Kolmogorov-Smirnov test and AndersonDarling test were used along with the chisquare test at $\alpha(0.01)$ level of significance for the selection of the best fit probability distribution (Sharma and Singh, 2010).

\section{Kolmogorov-Smirnov test}

In statistics, the Kolmogorov-Smirnov test (Chakravart, Laha and Roy, 1967) is a nonparametric test of the equality of continuous, one-dimensional probability distributions that can be used to compare a sample with a reference probability distribution. The Kolmogorov-Smirnov statistic quantifies a distance between the empirical distribution function of the sample and the cumulative distribution function of the reference distribution. The KolmogorovSmirnov statistic (D) is defined as the largest vertical difference between the theoretical and the Empirical Cumulative Distribution Function (ECDF):

$$
D=\max _{1 \leq i \leq n}\left(F\left(x_{i}\right)-\frac{i-1}{n}, \frac{i}{n}-F\left(x_{i}\right)\right)
$$

Where, $\mathrm{X}_{\mathrm{i}}=$ random sample, $\mathrm{i}=1,2 \ldots, \mathrm{n}$

$$
C D F=F_{n}(x)=\frac{1}{n}[\text { Numberofobservations } \leq x]
$$

This test was used to decide if a sample comes from a hypothesized continuous distribution.

\section{Anderson-Darling test}

The Anderson-Darling test (Stephens, 1974) is a statistical test of whether a given sample of data is drawn from a given probability distribution. In its basic form, the test assumes that there is no parameter to be estimated in the distribution being tested, in which case the test and its set of critical values is distribution free. However, the test is most often used in contexts where a family of distribution is being tested, in which case the parameters of that family need to be estimated and account must be taken of this in adjusting either the test-statistic or its critical values The Anderson-Darling statistic $\left(\mathrm{A}^{2}\right)$ is defined as:

$$
A^{2}=-n-\frac{1}{n} \sum_{i=1}^{n}(2 i-1)\left[\ln F\left(x_{i}\right)+\ln \left(1-F\left(x_{n-i+1}\right)\right]\right.
$$

It is a test to compare the fit of an observed cumulative distribution function to an expected cumulative distribution function. This test gives more weight to the tails then the Kolmogorov-Smirnov test.

\section{Chi-Squared test}

The Chi-Squared statistic is defined as

$\chi^{2}=\sum_{i=1}^{k} \frac{\left(O_{t}-E_{i}\right)^{2}}{E_{t}}$

Where,

$\mathrm{Oi}=$ observed frequency,

$\mathrm{Ei}=$ expected frequency,

' $\mathrm{i}$ '= number of observations $(1,2, \ldots \ldots . \mathrm{k})$

This test is for continuous sample data only and is used to determine if a sample comes from a population with a specific distribution (Sharma and Singh, 2010).

\section{Identification of best fit probability distribution}

The three goodness of fit tests mentioned above were fitted to the rainfall data. The test statistic of each test was computed and tested at $1 \% \quad(\alpha=0.01)$ level of significance. Accordingly the ranking of different probability distributions were marked. The distribution holding the first rank was selected for all the three tests independently. The assessments of all the probability distribution was made on the bases of total test score obtained by combining the entire three tests. 


\section{Least square method}

The least square method is used to identify the best fit probability. The random numbers were generated for the distributions and residuals (R) were computed for each observation of the data set.

$R=\sum_{i-1}^{n} \mid\left(Y_{i}-\left.\hat{Y}_{i}\right|^{2}\right.$

Where, $\mathrm{Y}_{i}=$ the actual observation

$\widehat{Y}_{\mathrm{I}}=$ the estimated observation $(\mathrm{i}=1,2, \ldots ., \mathrm{n})$

The distribution having minimum sum of residuals was considered to be the best fit probability distribution for that particular data set. Finally the best fit probability distributions for weather parameters on different sets of data were obtained and the best fit distribution for each set of data was identified.

\section{Software used}

The data is analyzed by a computer-based routine EASYFIT 5.6 package for fitting probability distribution function that also provides goodness of fit tests.

\section{Water balance}

The water balance is a detailed statement of the law of conservation of energy, which states that matter can neither be created nor be destroyed but can only be changed from one state or location to another. If above statement is applied to the hydrologic equations, it states that, in a specified period of time, all water entering a specified area must either go into storage within its boundaries, be consumed there in, be exported therefore or flow out either on the surface or underground.

So for its computation procedure introduced by Thornthwaite and Mather, (1955) was used. Thornthwaite and Mather (1955) suggested the use of potential evapotranspiration (PET) value for comparison of soil water balance. Because of ambiguities in the interpretation of potential evapotranspiration, the term reference evapotranspiration $\left(\mathrm{ET}_{0}\right)$ is used throughout the world. Therefore the original equation of Thornthwaite and Mather (1955) was modified by using $\mathrm{ET}_{0}$ in place of PET. The central concept of soil water balance is shown in Fig. 1

The rainfall data of study area for a period of 1981 to 2017 were obtained from the meteorological observatory of Junagadh.

\section{Concept of water balance}

The general water balance equation may be given as:

$$
(\mathbf{P}+\mathbf{I})=\mathbf{E T}+\mathbf{R}+\mathbf{D} \pm \Delta \mathbf{S}
$$

Where,

$\mathrm{P}=$ Rainfall, $(\mathrm{mm})$,

$\mathrm{I}=$ Irrigation, $(\mathrm{mm})$,

$\mathrm{ET}=$ Evapotranspiration, $(\mathrm{mm})$

$\mathrm{R}=$ Surface runoff, $(\mathrm{mm})$.

$\mathrm{D}=$ Deep drainage, $(\mathrm{mm})$.

$\Delta S=$ Change in soil moisture, $(\mathrm{mm})$

\section{Available water holding capacity of soil (AWC)}

The field capacity, permanent wilting point, depth of soil column and dry bulk density of soil of this study area representing the whole area (Junagadh) are taken as $23.77 \%, 13 \%$, 100 to $130 \mathrm{~mm}$ and $1.51 \mathrm{gm} / \mathrm{cc}$ (Chandulal, 2018).

The available water holding capacity in terms of depth was calculated as follows:

$\mathrm{AWC}=\frac{(\mathrm{FC}-\mathrm{PWP}) \times \mathrm{p}_{\mathrm{b}} \times \mathrm{D}}{100}$ 
Where,

AWC = Available water holding capacity equivalent to the depth of water $(\mathrm{cm})$

$\mathrm{FC}=$ Field capacity $(\%)$

PWP $=$ Permanent wilting point $(\%)$

$\mathrm{P}_{\mathrm{b}}=$ Bulk density $(\mathrm{gm} / \mathrm{cc})$

$\mathrm{D}=$ Depth of soil column $(\mathrm{cm})$.

\section{Reference evapotranspiration $\left(\mathbf{E T}_{\mathbf{0}}\right)$}

According to this definition reference evapotranspiration $\left(\mathrm{ET}_{0}\right)$ was computed as the procedure given by Allen et al., (1998) in FAO-56.

$\mathrm{ET}_{0}=\frac{0.408 \Delta\left(\mathrm{R}_{\mathrm{n}}-\mathrm{G}\right)+\frac{900}{\mathrm{~T}+\mathrm{Z73}} \mathrm{U}_{\mathrm{z}}\left(\mathrm{E}_{\mathrm{z}}-\mathrm{E}_{\mathrm{d}}\right)}{\Delta+\mathrm{Y}\left(1+.34 \mathrm{U}_{\mathrm{Z}}\right)}$

Where,

$\mathrm{ET}_{0}=$ Reference evapotranspiration $\left(\right.$ mmday $^{-1}$ )

$\mathrm{R}_{\mathrm{n}}=$ Net radiation $\left(\mathrm{MJm}^{-2}\right.$ day $)=\mathrm{R}_{\mathrm{ns}}-\mathrm{R}_{\mathrm{nl}}$

$\mathrm{R}_{\mathrm{ns}}=$ Net short wave radiation $\left(\mathrm{MJm}^{-2}\right.$ day)

$\mathrm{R}_{\mathrm{nl}}=$ Net long wave radiation $\left(\mathrm{MJm}^{-2}\right.$ day)

$\Delta=$ Slope of the saturation vapour pressure function $\left(\mathrm{kPa}^{0} \mathrm{c}^{-1}\right)$

$\mathrm{G}=$ Soil heat flux ( $\mathrm{MJm}^{-2}$ day)

$\mathrm{Y}=$ Psychometric constant $\left(\mathrm{kPa}^{0} \mathrm{c}^{-1}\right)$

$\mathrm{T}=$ Mean daily temperature $\left(0_{\mathrm{c}}\right)$

$\mathrm{e}_{\mathrm{a}}=$ Saturation vapour pressure at temperature

$\mathrm{T}(\mathrm{kPa})$

$\mathrm{e}_{\mathrm{d}}=$ Saturation vapour pressure at dew point $(\mathrm{kPa})$

$\mathrm{U}_{2}=$ Average daily wind speed at $2 \mathrm{~m}$ height $\left(\mathrm{ms}^{-1}\right)$

\section{Weekly moisture excess and deficit (P-ET $\left.)_{0}\right)$}

Difference between rainfall $(\mathrm{P})$ and reference evapotranspiration gives weekly moisture excess and deficit. A negative value of this difference indicates moisture deficit, which means the amount by which the rainfall fails to supply the potential water need of area. While positive difference indicates excess moisture, this is the amount of excess water available for soil moisture replenishment and also for a runoff.

\section{Thornthwaite method}

Climatic water balance consists of precipitation, potential evapotranspiration, actual evapotranspiration, soil moisture storages, surplus and deficit. The models take the difference between weekly precipitation and evapotranspiration, and carry forward a balance of water surplus or deficiency. A first requirement is the water holding capacity of the soil relative to soil type and land use.

The weekly soil water balance was computed following the procedure by Thornthwaite and Mather (1995). The actual storage of soil moisture can be determined by the following equation.

$\mathrm{STOR}=A W C \mathrm{e}^{\frac{\mathrm{ACO}(\mathrm{P}-\mathrm{ETO})}{\mathrm{AWc}}}$

Where,

STOR $=$ Actual storage soil moisture, $(\mathrm{mm})$

AWC =Moisture storage capacity of soil, (mm)

$\mathrm{P}=$ Precipitation, $(\mathrm{mm})$

$\mathrm{ET}_{\mathrm{O}}=$ Reference evapotranspiration, $(\mathrm{mm})$

$\mathrm{ACC}=$ Accumulation water in system, $(\mathrm{mm})$

\section{Change in storage $\left({ }^{\Delta}\right.$ STOR $)$}

The positive changes in soil storage are termed as soil moisture recharge. The negative changes are termed as soil moisture utilization, when the value in storage is above the water holding capacity; it was assumed that there is no change in soil storage.

\section{Actual evapotranspiration (AET)}

The actual evapotranspiration (AET) was considered to take place at the potential rate, when precipitation exceeds the potential evapotranspiration during particular week and 
also when moisture in the soil is near field capacity. However, after the soil moisture was depleted to a point where the ability of the soil to transmit the moisture was reduced. The actual rate of evapotranspiration was sharply reduced. Therefore weekly actual evapotranspiration was calculated by following equations:

a) When $\mathrm{P}>\mathrm{ET}_{0}$

$\mathrm{AET}=\mathrm{ET}_{0}$

b) When $\mathrm{P}<\mathrm{ET}_{0}$

$\mathrm{AET}=\mathrm{P}+\operatorname{abs}\left({ }^{\Delta} \mathrm{STOR}\right)$

From the above equations it is clear that when precipitation is less than $\mathrm{ET}_{0}$, then $\mathrm{AET}$ is equal to precipitation plus absolute value of change in the soil moisture storage than previous week.

\section{Water deficit (DEF)}

The amount by which the actual evapotranspiration (AET) and reference evapotranspiration differ in any week is the water deficit (DEF). Water deficit only exists when $\left(\mathrm{P}-\mathrm{ET}_{0}\right)$ is negative and is calculated by the equation,

$\mathrm{DEF}=\mathrm{ET}_{\mathrm{o}}-\mathrm{AET}$

\section{Water surplus (SUR)}

The water surplus is the amount of positive $\left(\mathrm{P}-\mathrm{ET}_{0}\right)$ which remains in excess after recharging the soil to the field capacity by the equation,

$\mathrm{SUR}=\mathrm{P}-\mathrm{AET}$

\section{Software used}

The reference evapotranspiration is estimated by above method using CROPWET 8.0 software.

\section{Crop water requirement $\left(\mathbf{E} \mathbf{T}_{\mathbf{C}}\right)$}

The estimation of the water requirement (WR) of crops is one of the basic needs for crop planning on the farm. Water requirement includes the losses due to evapotranspiration or consumptive use plus the losses during the application of water the quantity of water required for special operation like land preparation, pre-sowing irrigation and transplanting.

\section{Crop evaportranspiration}

This is the crop evaportranspiration under standard condition $\left(\mathrm{ET}_{\mathrm{c}}\right)$ where no limitations are placed on crop growth. In the coefficient approach the crop potential evaportranspiration, $\mathrm{ET}_{\mathrm{c}}$ was calculated by multiplying the daily reference evapotranspiration $\left(\mathrm{ET}_{\mathrm{o}}\right)$ with crop coefficient $\left(K_{c}\right)$ value (Doorenbos and Pruitt 1975).

$\mathrm{ET}_{\mathrm{c}}=\mathrm{K}_{\mathrm{c}} \times \mathrm{ET}_{\mathrm{o}}$

Where,

$\mathrm{ET}_{\mathrm{c}}=$ Crop water requirement $\left(\mathrm{mm} \mathrm{d}^{-1}\right)$

$\mathrm{K}_{\mathrm{c}}=$ Crop coefficient (dimensionless)

$\mathrm{ET}_{\mathrm{o}}=$ reference evapotranspiration $\left(\mathrm{mm} \mathrm{d}^{-1}\right)$

The daily $\mathrm{ET}_{\mathrm{c}}$ computed were summed for different growth stages (initial, developmental, mid-season and late season) of crop and seasonal crop water was determined. $\mathrm{K}_{\mathrm{c}}$ values for different crops are taken as suggested by Mehta and Pandey (2016).

\section{Results and Discussion}

\section{Rainfall analysis}

The weekly data for a period of 37 years (1981 to 2017) are analyzed and is presented in Table 3. 
The lowest mean value of $7.72 \mathrm{~mm}$ is observed in $23^{\text {rd }}$ SMW and the highest mean value of weekly rainfall of $94.19 \mathrm{~mm}$ was observed in the $29^{\text {th }}$ SMW followed by mean value of $83.13 \mathrm{~mm}$ in the $25^{\text {th }} \mathrm{SMW}$. The highest weekly rainfall of $1390 \mathrm{~mm}$ occurred in the $25^{\text {th }}$ SMW during the 1983. The highest value of standard deviation is observed in the $25^{\text {th }} \mathrm{SMW}$. The standard deviation is very high indicating the high fluctuation of mean rainfall. The highest value of coefficient of variation is observed in the $42^{\text {th }} \mathrm{SMW}$. The coefficient of variability $(\mathrm{CV})$ indicates the dependability or reliability on rainfall for any period. The $\mathrm{CV}$ of weakly rainfall in the beginning and ending of season is quite high (Table 3). The weeks with $\mathrm{CV}$ value up to $150 \%$ are dependable and above $150 \%$ are unreliable (Singh, 1978). The higher values of skewness indicate the asymmetrical distribution of weekly rainfall at Junagadh. The rainfall distribution in most of the weeks is mostly leptokurtic and skewed to the right.

\section{Fitting of probability distribution}

Analysis of rainfall data strongly depends on distribution pattern. The statistic value of Anderson Darling distribution, Kolmogorov Smirnov and Chi-square tests are computed for a set of probability distribution. The best fit probability distribution is identified based on highest rank obtained in the entire three tests independently. The parameters of the best fit probability distribution of rainfall are evaluated. The best fit probability distribution for rainfall is identified using the least squares method. The weekly best fit probability distribution for rainfall is given in Table 4.

For weekly rainfall (Table 4.), Gamma distribution is found to be the best fit distribution for SMW 24, 26, 28, 29, 32 and 42 SMW, which shows flexibility yielding a wide variety of shape of probability distribution. Gen. Extreme Value distribution is found to be the best fit distribution for SMW 23, 25, 27, 30, 31, and 33 to 39 which shows characterizes either the largest or smallest extreme value. Gumbel maximum distribution is found to be the best fit distribution for SMW 40 and 41 which shows higher peak than normal distribution. Similar results were obtained by Dwivedi et al., (2017).

\section{Prediction of weekly rainfall at different levels af probabilities by using gamma distribution and general extreme value distribution}

To follow the profitable cropping system under rainfed condition, the primary need of the farmers is to know when and where to sow and reap for successful cultivation with proper utilization of available rain water. Since the water requirement of most of the crops are known, the information on receiving a particular amount of rainfall is more successful than chances of their occurrence. So suitable crop planning can be suggested by determining the probability $(\%)$ of receiving particular amount of rainfall in a week. Weekly rainfall was predicted by using 37 years rainfall data at different probability level using Gen. Extreme Value distribution and Gamma distribution from $23^{\text {rd }}$ SMW to $42^{\text {nd }}$ SMW. Whereas it was predicated by Generalized Extreme Value distribution and Gumbel maximum in $40^{\text {th }}$ and $41^{\text {st }}$ SMW and is given in Table 5.

Weekly rainfall at different probability levels by Gamma distribution (Table 5) showed that from $24^{\text {th }}$ SMW (11-17 June) onwards $25 \mathrm{~mm}$ or more rainfall per week is expected except $26^{\text {th }}$ SMW at $50 \%$ probability level. This is corresponding to time for onset of monsoon in Saurashtra region of Gujarat. At $75 \%$ probability level rainfall is expected is range of 8.7-21.5 mm per week up to $33^{\text {th }} \mathrm{SMW}$ after this decrease of probabilistic rainfall is 
observed. Weekly rainfall at different probability levels by Generalized extreme value distribution (Table 5) showed that from $24^{\text {th }} \mathrm{SMW}$ onwards more than $20 \mathrm{~mm}$ rainfall per week is expected at $75 \%$ probability expect $25^{\text {th }}$ and $26^{\text {th }}$ SMW. At $90 \%$ probability level rainfall is expected in the range of 21-34.8 mm per week up to 32 SMW from $27^{\text {th }}$ SMW. Decrease at probabilistic rainfall is observed after 32 SMW. Similar results were obtained by Alam et al., (2016).Weekly rainfall at different probability levels by Gumbel maximum distribution (Table 5) showed that more than $20 \mathrm{~mm}$ rainfall per week is expected at $75 \%$ probability in $41^{\text {st }}$ SMW. At $90 \%$ probability level rainfall is calculated as $3.4 \mathrm{~mm}$ and 5 $\mathrm{mm}$ per week in $40^{\text {th }}$ and $41^{\text {st }} \mathrm{SMW}$.

\section{Weekly water balance-thornthwaite- method}

Water balance elements of Junagadh regions are computed on weekly basis using Thornthwaite-method. Values of weekly water balance elements are shown in Table 6 .

\section{Reference evapotranspiration $\left(\mathbf{E T}_{\mathbf{0}}\right)$}

Weekly values of $\mathrm{ET}_{0}$ are computed by Penman-Monteith equation and shown in Table 6. Variation of weekly reference evapotranspiration is shown in Fig. 2. $\mathrm{ET}_{0}$ values are revealed that more than $50 \mathrm{~mm}$ is observed from $16^{\text {th }}$ to $18^{\text {th }}$ SMW. This may be due to higher temperature, more number of sunshine hours during the day, lesser humidity and more windy conditions.

Due to lower temperature, higher humidity and lesser sunshine hours, the $\mathrm{ET}_{0}$ values start declining with commencement of winter. The minimum of weekly $\mathrm{ET}_{0}$ of $20-30 \mathrm{~mm}$ is observed in $1^{\text {st }}, 24^{\text {th }}, 34^{\text {th }}$ to $37^{\text {th }}$ week and $47^{\text {th }}$ to $50^{\text {th }}$ week. The medium of weekly $\mathrm{ET}_{\mathrm{o}}$ of $30-40 \mathrm{~mm}$ is observed in $2^{\text {nd }}, 3^{\text {rd }}, 11^{\text {st }}$ to $13^{\text {rd }}$, $22^{\text {nd }}$ to $33^{\text {rd }}, 38^{\text {th }}, 39^{\text {th }}, 45^{\text {th }}, 46^{\text {th }}, 51^{\text {st }}$ and $52^{\text {nd }}$ week.

\section{Actual evapotranspiration (AET)}

Variation of weekly actual evapotranspiration is shown in Table 6. Figure 2.Reveal that AET is the function of $\mathrm{P}, \mathrm{ET}_{0}$ and available soil moisture. The value of AET is high in monsoon, during this period it closely matches with $\mathrm{ET}_{0}$ because of precipitation and accreted moisture of that period but it starts declining during winter season and its value is lowest in the summer.

\section{Moisture status}

Elements of weekly water balance have been computed for the period 1981-2017. Weekly water balance components are summed up for weekly values and are given in Table 6 . Results revealed that during wettest SMW $30^{\text {th }}, \mathrm{ET}_{0}$ is found to be $37.70 \mathrm{~mm}$, AET is $37.70 \mathrm{~mm}$, soil moister is $187 \mathrm{~mm}$ and water surplus is $42.80 \mathrm{~mm}$. During the driest SMW $17^{\text {th }}, \mathrm{ET}_{0}$ is $51.50 \mathrm{~mm}$, AET is $0 \mathrm{~mm}$, soil moisture is $0 \mathrm{~mm}$, water deficit is $51.40 \mathrm{~mm}$ and water surplus is $0 \mathrm{~mm}$. Water surplus is observed from $29^{\text {th }}$ to $38^{\text {th }}$ week. In the remaining period, there is deficit of moisture.

\section{Water requirement of crops}

It is the total water needed for maximum evapotranspiration from planting to harvest for a given crop in a specific climatic region, when adequate soil water is maintained by rainfall or irrigation so that it is does not limit plant growth and crop yield. Assuming seepage and percolation losses in fields are negligible.

\section{Crop coefficient}

Crop coefficients are affected by the crop characteristics, time of sowing, stage of crop 
development and climate conditions. For determining the crop coefficient, crop development is considered in four stages i.e. initial stage, crop developmental stage, midseason stage and late season stage. The length of growing season for bunch and spreading groundnut are taken as 98 days $\left(27^{\text {th }}-40^{\text {th }}\right.$ SMW), 120 days $\left(27^{\text {th }}-44^{\text {th }}\right.$ SMW) whereas in cotton it is taken as 200 days $\left(27^{\text {th }}-3^{\text {rd }}\right.$ SMW). The length of growing season of wheat is taken as 120 days $\left(46^{\text {th }}-10^{\text {th }}\right.$ SMW $)$. The crop coefficients for groundnut, cotton and wheat crops at different crop growth stages are taken as suggested by Doorenbos and Pruitt, (1975) and are shown in Table 7.

\section{Crop evapotranspiration}

Crop water requirement is calculated as given in section 3.11.1 considering $27^{\text {th }}$ SMW for kharif crops and $46^{\text {th }}$ SMW for wheat crop as sowing week to harvest. In the present study $27^{\text {th }}$ SMW is considered as sowing date because there are 90, 75, 50, 25 and 10 percent probability of getting more than $22.53,28.36,42.27,62.79$ and $77.46 \mathrm{~mm}$ rainfall. Stage wise water requirement of kharif cotton groundnut (bunch), groundnut (spreading) and wheat is presented in Table 8. to 11

The stage wise crop water requirement of different crops (Table 7.) suggested that among kharif season crops cotton has the highest $\mathrm{ET}_{\mathrm{c}}(818.42 \mathrm{~mm})$ followed by spreading groundnut $\mathrm{ET}_{\mathrm{c}}(414.08 \mathrm{~mm})$. Bunch groundnut $(338.63 \mathrm{~mm})$ has the lowest $\mathrm{ET}_{\mathrm{c}}$. During the initial stage of the crops, cotton has the highest $(47.61 \mathrm{~mm})$ water requirement followed by spreading groundnut $(41.91 \mathrm{~mm})$ and bunch groundnut $(40.88 \mathrm{~mm})$. During developmental stage the $\mathrm{ET}_{\mathrm{c}}$ for different crops varied between 174.90 to $89.85 \mathrm{~mm}$, highest being in cotton and lowest in groundnut. Mid-season is the longest stage of the crops during which water requirement is also maximum. ET $_{\mathrm{c}}$ of different crops during mid-season varied between 361.89 to 135.69 $\mathrm{mm}$. During late season the water requirement decreases, hence depending upon the duration of the crops the total $\mathrm{ET}_{\mathrm{c}}$ of different crops varied between 234.01 to $82.21 \mathrm{~mm}$, the highest being in cotton and lowest in groundnut (bunch). Wheat is the major rabi crop in Junagadh district. The crop water requirement $\left(\mathrm{ET}_{\mathrm{c}}\right)$ of wheat crop $581.28 \mathrm{~mm}$ shown in (Table 7.). During initial stage of the crops $\mathrm{ET}_{\mathrm{c}}$ of $33.51 \mathrm{~mm}$ and developmental stage has total $\mathrm{ET}_{\mathrm{c}}$ of 172.38 $\mathrm{mm}$. During mid-season stage, the total $\mathrm{ET}_{\mathrm{c}}$ of $290.17 \mathrm{~mm}$. The total $\mathrm{ET}_{\mathrm{c}}$ during late season stage $85.20 \mathrm{~mm}$. Similar results were obtained by Mehta and Pandey (2016).

\section{Planning of agricultural crops}

In an rainfed agro-ecosystem it is essential to plan agriculture by making best use of rainfall potential. Estimates of the magnitude and duration of water deficit and surplus are of the vital importance for crop planning crop and water management practices to promote crop production in both irrigated and dry land areas. The coefficient of variation in the $27^{\text {th }}$ $38^{\text {th }}$ SMW ranged from 115.98 to $135.56 \%$ except $33^{\text {rd }}$ and $37^{\text {th }}$ SMW, therefore they are dependable.

Therefore crop activities like land preparation should be carried out during $24^{\text {th }}$ SMW. Kharif crops are sown on receipt of a good rain spell at the beginning of the monsoon season, indicating the start of the rains. Timely sowing is a most important criterion for achieving high crop yields. The rainfall occurrence is observed 28.36, 42.27and 62.79 $\mathrm{mm}$ at 75,50 and 25 percent probability during $27^{\text {th }}$ SMW. Therefore supplementary irrigation should be applied to the crops during these periods. Spraying can therefore be taken up quite safely after $39^{\text {th }}$ SMW due to high probability of dry spells. 
Table.1 Description of various probability distributions

\begin{tabular}{|c|c|c|c|}
\hline Sr.no & Distribution & Probability density function & Range \\
\hline 1 & Lognormal & $f(X)=\frac{1}{X\left(v^{2} 2 \pi \sigma^{2}\right.} \exp \left\{\frac{-(x n x-\mu)^{2}}{2 \sigma^{2}}\right\}$ & $\begin{array}{c}0 \leq X \leq \infty \\
-x<\mu<\infty \\
\sigma>0\end{array}$ \\
\hline 2 & Gamma & $f(X)=\frac{1}{\beta^{\alpha} \alpha !} X^{\Phi-1} e^{-x_{\beta} / \beta}$ & $\begin{array}{c}0 \leq X \leq \infty \\
\alpha \geq 0 x \\
\beta \geq 0\end{array}$ \\
\hline 3 & $\begin{array}{l}\text { Inverse } \\
\text { Gaussian }\end{array}$ & $f(x)=\left[\frac{\gamma}{2 \pi x^{2}}\right]^{\frac{1}{2}} \exp \frac{-\gamma(x-\mu)^{2}}{2 \mu^{2} x}$ & $\begin{array}{l}x>0, x \\
\mu>0 \\
y>0\end{array}$ \\
\hline 4 & $\begin{array}{l}\text { Generalized } \\
\text { Extreme value }\end{array}$ & $f(X)=\frac{1}{\sigma}\left[1-k\left(\frac{x-\mu}{\sigma}\right]^{\frac{1}{k-1}} \exp \left[-\left\{1-k\left(\frac{x-\mu}{\sigma}\right)\right]^{\frac{1}{k}}\right.\right.$ & $\begin{aligned}-\infty & \leq X \leq \infty \\
\mathrm{k} & \neq 0\end{aligned}$ \\
\hline 5 & Weibull & $f(X)=\frac{\alpha}{\beta}\left(\frac{x}{\beta}\right)^{\alpha-1} \exp \left\{-\left(-\frac{x}{\beta}\right)^{\alpha}\right\}$ & $y \leq X+\infty$ \\
\hline 6 & $\begin{array}{l}\text { Gumbel } \\
\text { maximum }\end{array}$ & $f(x)=\frac{1}{\sigma} \exp \left[-\left(\frac{x-\mu}{\sigma}\right)-\exp \left\{-\left(\frac{x-\mu}{\sigma}\right)\right\}\right]$ & $-\infty<X<+\infty$ \\
\hline
\end{tabular}

Table. $2 \mathrm{~K}_{\mathrm{c}}$ value for different growth stages (initial, developmental, mid-season and late season)

\begin{tabular}{|l|c|c|c|c|}
\hline Crop & Initial stage & Developmental Stage & mid-season & late season \\
\hline Cotton & 0.4 to 0.5 & 0.7 to 0.8 & 1.05 to 1.25 & 0.8 to 0.9 \\
\hline Groundnut & 0.4 to 0.5 & 0.7 to 0.8 & 0.95 to 1 & 0.75 to 0.85 \\
\hline Wheat & 0.4 & 1.15 & 1.20 & 0.42 \\
\hline
\end{tabular}

Table.3 Descriptive statistics of weekly rainfall

\begin{tabular}{|c|c|c|c|c|c|c|}
\hline \multirow{2}{*}{ Dates } & SMW & \multicolumn{5}{|c|}{ Weekly Rainfall (mm) } \\
\cline { 4 - 7 } & & Max. & Mean & SD & CV $(\%)$ & Skewness \\
\hline 04-10 June & 23 & 67.20 & 7.72 & 15.36 & 198.94 & 2.44 \\
\hline 11-17 June & 24 & 426.00 & 62.49 & 94.60 & 151.37 & 2.09 \\
\hline 18-24 June & 25 & 1390.00 & 83.13 & 232.76 & 279.97 & 5.04 \\
\hline 25-1 July & 26 & 246.40 & 35.72 & 62.79 & 175.78 & 2.39 \\
\hline 2-8 July & 27 & 273.00 & 63.16 & 73.26 & 115.98 & 1.34 \\
\hline 9-15 July & 28 & 454.20 & 79.72 & 98.84 & 123.98 & 2.03 \\
\hline 16-22 July & 29 & 412.00 & 94.19 & 108.18 & 114.85 & 1.72 \\
\hline 23-29 July & 30 & 359.40 & 80.56 & 87.63 & 108.76 & 1.45 \\
\hline 30-5 August & 31 & 298.60 & 76.32 & 92.21 & 120.82 & 1.11 \\
\hline 6-12 August & 32 & 382.40 & 66.38 & 82.33 & 124.023 & 2.10 \\
\hline 13-19 August & 33 & 411.90 & 43.41 & 70.29 & 161.925 & 4.14 \\
\hline 20-26 August & 34 & 137.50 & 27.64 & 34.48 & 124.75 & 1.80 \\
\hline 27-2 September & 35 & 244.60 & 34.31 & 49.56 & 144.45 & 2.62 \\
\hline 3-9 September & 36 & 174.10 & 35.14 & 51.96 & 147.86 & 1.45 \\
\hline 10-16 September & 37 & 444.20 & 47.41 & 90.65 & 191.18 & 3.26 \\
\hline 17-23 September & 38 & 223.00 & 43.17 & 58.52 & 135.56 & 1.71 \\
\hline 24-30 September & 39 & 248.20 & 25.72 & 44.19 & 171.81 & 3.67 \\
\hline 1-7 October & 40 & 113.91 & 16.57 & 33.63 & 202.89 & 2.19 \\
\hline 8-14 October & 41 & 55.20 & 3.47 & 9.87 & 284.53 & 4.20 \\
\hline 15-21 October & 42 & 59.70 & 2.06 & 9.81 & 474.45 & 5.73 \\
\hline
\end{tabular}


Table.4 Parameters of the distributions fitted for rainfall data sets and best fit distribution

\begin{tabular}{|c|c|c|c|}
\hline (SMW) & Distributions & Parameters & Remarks \\
\hline \multirow[t]{2}{*}{23} & Gen. Extreme Value & $\mathrm{K}=0.67184 \sigma=2.6707 \mu=0.87199$ & Best fit \\
\hline & Gamma & $\alpha=0.24584 \beta=31.409$ & \\
\hline \multirow[t]{2}{*}{24} & Gumbel Max. & $\sigma=6.9218 \mu=2.5359$ & \\
\hline & Gamma & $\alpha=0.02703 \beta=54$ & Best fit \\
\hline 25 & Gen. Extreme Value & $\mathrm{K}=0.75614 \sigma=20.799 \mu=8.2539$ & Best fit \\
\hline \multirow[t]{2}{*}{26} & Gen. Extreme Value & $\mathrm{K}=0.58904 \sigma=14.887 \mu=6.4626$ & \\
\hline & Gamma & $\alpha=0.31487 \quad \beta=113.45$ & Best fit \\
\hline 27 & Gen. Extreme Value & $\mathrm{K}=0.30123 \sigma=38.76 \mu=24.562$ & Best fit \\
\hline \multirow[t]{2}{*}{28} & Gamma & $\alpha=0.63297 \beta=125.95$ & Best fit \\
\hline & Gen. Extreme Value & $\mathrm{K}=0.35582 \sigma=44.825 \mu=29.842$ & \\
\hline \multirow[t]{2}{*}{29} & Gamma & $\alpha=0.73763 \beta=127.7$ & Best fit \\
\hline & Weibull & $\alpha=0.74519 \quad \beta=79.36$ & \\
\hline \multirow[t]{3}{*}{30} & Lognormal & $\sigma=1.5867 \mu=3.6583$ & \\
\hline & Gen. Extreme Value & $\mathrm{K}=0.2635 \sigma=49.296 \mu=34.954$ & Best fit \\
\hline & Gamma & $\alpha=0.75993 \beta=112.07$ & \\
\hline \multirow[t]{3}{*}{31} & Lognormal & $\sigma=1.8614 \mu=3.3714$ & \\
\hline & Gen. Extreme Value & $\mathrm{K}=0.30754 \sigma=48.685 \mu=27.22$ & Best fit \\
\hline & Weibull & $\alpha=0.30544 \beta=40.116$ & \\
\hline \multirow[t]{2}{*}{32} & Gamma & $\alpha=0.63255 \beta=104.94$ & Best fit \\
\hline & Gen. Extreme Value & $\mathrm{K}=0.39561 \sigma=34.217 \mu=24.934$ & \\
\hline 33 & Gen. Extreme Value & $\mathrm{K}=0.5104 \sigma=18.137 \mu=14.646$ & Best fit \\
\hline \multirow[t]{2}{*}{34} & Gamma & $\alpha=0.62517 \quad \beta=44.213$ & \\
\hline & Gen. Extreme Value & $\mathrm{K}=0.38834 \sigma=14.712 \mu=10.099$ & Best fit \\
\hline \multirow[t]{2}{*}{35} & Gen. Extreme Value & $\mathrm{K}=0.45524 \sigma=17.205 \mu=10.464$ & Best fit \\
\hline & Gamma & $\alpha=0.46628 \beta=73.584$ & \\
\hline \multirow[t]{2}{*}{36} & Gen. Extreme Value & $\mathrm{K}=0.46356 \sigma=19.078 \mu=8.1724$ & Best fit \\
\hline & Gumbel Max. & $\sigma=41.073 \mu=11.432$ & \\
\hline \multirow[t]{2}{*}{37} & Gamma & $\alpha=0.26618 \beta=178.12$ & \\
\hline & Gen. Extreme Value & $\mathrm{K}=0.61409 \sigma=18.142 \mu=8.9679$ & Best fit \\
\hline \multirow[t]{2}{*}{38} & Gen. Extreme Value & $\mathrm{K}=0.39658 \sigma=24.955 \mu=12.875$ & Best fit \\
\hline & Gumbel Max. & $\sigma=46.256 \mu=16.468$ & \\
\hline 39 & Gen. Extreme Value & $\mathrm{K}=0.49402 \sigma=12.678 \mu=6.426$ & Best fit \\
\hline \multirow[t]{2}{*}{40} & Gumbel Max. & $\sigma=26.587 \mu=1.2319$ & Best fit \\
\hline & Weibull & $\alpha=0.2064 \beta=0.99592$ & \\
\hline \multirow[t]{2}{*}{41} & Gumbel Max. & $\sigma=7.869 \mu=1.0345$ & Best fit \\
\hline & Weibull & $\alpha=0.3442 \quad \beta=0.86488$ & \\
\hline \multirow[t]{2}{*}{42} & Gumbel Max. & $\sigma=7.7609 \mu=2.4662$ & \\
\hline & Gamma & $\alpha=0.04092 \quad \beta=49.206$ & Best fit \\
\hline
\end{tabular}


Table.5 Minimum assured rainfall in different SMW at different probability levels

\begin{tabular}{|c|c|c|c|c|c|c|c|c|c|c|}
\hline \multirow[t]{3}{*}{ SMW } & \multicolumn{10}{|c|}{ Weekly Rainfall (mm) at Probability level (\%) } \\
\hline & \multicolumn{2}{|c|}{90} & \multicolumn{2}{|c|}{75} & \multicolumn{2}{|c|}{50} & \multicolumn{2}{|c|}{25} & \multicolumn{2}{|c|}{10} \\
\hline & G.E.V.D & G.D & G.E.V.D & G.D & G.E.V.D & G.D & G.E.V.D & G.D & G.E.V.D & G.D \\
\hline 23 & 0.8 & 0.2 & 1.1 & 1.1 & 2.0 & 4.4 & 5.29 & 11.7 & 15.58 & 23.0 \\
\hline 24 & 19.01 & 0.5 & 23.35 & 4.5 & 34.26 & 25.0 & 52.84 & 81.6 & 69.16 & 177 \\
\hline 25 & 14.9 & 0.1 & 17.81 & 3.4 & 25.54 & 26.1 & 41.32 & 102.3 & 60.22 & 242.4 \\
\hline 26 & 8.0 & 0.4 & 10.22 & 3.2 & 16.69 & 15.6 & 32.49 & 48.0 & 55.09 & 100.8 \\
\hline 27 & 22.53 & 1.9 & 28.36 & 9.3 & 42.27 & 33.8 & 62.79 & 87.0 & 77.46 & 166.9 \\
\hline 28 & 28.38 & 3.1 & 34.47 & 13.3 & 48.25 & 44.8 & 67.25 & 110.3 & 80.18 & 206.2 \\
\hline 29 & 34.8 & 6.3 & 41.45 & 21.5 & 55.57 & 61.0 & 73.14 & 135.1 & 83.99 & 238.2 \\
\hline 30 & 31.32 & 5.0 & 38.05 & 17.5 & 52.55 & 50.8 & 70.78 & 114.1 & 82.12 & 202.8 \\
\hline 31 & 28.64 & 1.5 & 34.56 & 8.7 & 47.57 & 36.7 & 64.90 & 102.7 & 76.64 & 205.9 \\
\hline 32 & 21.51 & 3.9 & 13.32 & 14.0 & 40.87 & 40.7 & 63.14 & 91.8 & 80.10 & 163.6 \\
\hline 33 & 10.19 & 2.8 & 13.32 & 9.7 & 22.77 & 27.8 & 45.44 & 62.1 & 73.17 & 110.0 \\
\hline 34 & 5.43 & 1.8 & 7.64 & 6.0 & 15.03 & 16.5 & 35.50 & 36.0 & 63.94 & 62.9 \\
\hline 35 & 7.96 & 1.2 & 10.60 & 5.6 & 18.73 & 20.2 & 38.69 & 51.9 & 64.21 & 99.4 \\
\hline 36 & 8.99 & 0.5 & 11.73 & 3.3 & 19.77 & 15.8 & 37.95 & 47.9 & 59.76 & 100.1 \\
\hline 37 & 11.37 & 0.6 & 14.18 & 4.6 & 22.11 & 22.5 & 39.67 & 68.6 & 61.52 & 143.7 \\
\hline 38 & 12.45 & 0.5 & 16.22 & 3.7 & 26.69 & 16.8 & 47.33 & 49.7 & 67.54 & 102.4 \\
\hline 39 & 5.18 & 0.5 & 6.93 & 3.0 & 12.55 & 12.8 & 28.26 & 36.2 & 53.60 & 73.0 \\
\hline 42 & 14.9 & 0.1 & 17.81 & 0.6 & 25.54 & 2.1 & 41.32 & 5.3 & 60.22 & 10.1 \\
\hline \multirow[t]{3}{*}{ SMW } & \multicolumn{10}{|c|}{ Weekly Rainfall (mm) at Probability level (\%) } \\
\hline & \multicolumn{2}{|c|}{90} & \multicolumn{2}{|c|}{75} & \multicolumn{2}{|l|}{50} & \multicolumn{2}{|l|}{25} & \multicolumn{2}{|l|}{10} \\
\hline & G.E.V.D & G.M & G.E.V.D & G.M & G.E.V.D & G.M & G.E.V.D & G.M & G.E.V.D & G.M \\
\hline 40 & 2.6 & 3.4 & 3.38 & 6.04 & 5.72 & 14.0 & 12.95 & 33.57 & 30.0 & 51.28 \\
\hline 41 & 10.0 & 5.0 & 25.0 & 25.0 & 50.04 & 3.5 & 75.0 & 74.62 & 89.53 & 89.86 \\
\hline
\end{tabular}

Table.6 Weekly Water balance-Thornthwaite-method $(\mathrm{AWC}=187 \mathrm{~mm})$

\begin{tabular}{|c|c|c|c|c|c|c|}
\hline Week & $\begin{array}{c}\text { Rainfall } \\
\mathbf{m m}\end{array}$ & $\begin{array}{c}\mathbf{E T} \\
\mathbf{m m}\end{array}$ & $\begin{array}{c}\text { Soil Moister } \\
\mathbf{m m}\end{array}$ & $\begin{array}{c}\text { AET } \\
\mathbf{m m}\end{array}$ & $\begin{array}{c}\text { Surplus } \\
\mathbf{m m}\end{array}$ & $\begin{array}{c}\text { Deficit } \\
\mathbf{M m}\end{array}$ \\
\hline $\mathbf{1}$ & 0.00 & 28.70 & 0 & 0 & 0 & 28.7 \\
\hline $\mathbf{2}$ & 0.10 & 31.90 & 0 & 0.1 & 0 & 31.7 \\
\hline $\mathbf{3}$ & 0.30 & 36.40 & 0 & 0.3 & 0 & 36.1 \\
\hline $\mathbf{4}$ & 0.00 & 42.20 & 0 & 0 & 0 & 42.2 \\
\hline $\mathbf{5}$ & 0.10 & 43.80 & 0 & 0.1 & 0 & 43.7 \\
\hline $\mathbf{6}$ & 0.00 & 44.20 & 0 & 0 & 0 & 44.2 \\
\hline $\mathbf{7}$ & 1.10 & 45.10 & 0 & 1.1 & 0 & 44 \\
\hline $\mathbf{8}$ & 0.00 & 45.80 & 0 & 0 & 0 & 45.8 \\
\hline $\mathbf{9}$ & 0.60 & 43.60 & 0 & 0.6 & 0 & 43.1 \\
\hline $\mathbf{1 0}$ & 0.20 & 41.10 & 0 & 0.2 & 0 & 40.9 \\
\hline $\mathbf{1 1}$ & 0.20 & 36.40 & 0 & 0.2 & 0 & 36.2 \\
\hline $\mathbf{1 2}$ & 0.00 & 36.10 & 0 & 0 & 0 & 36.1 \\
\hline
\end{tabular}




\begin{tabular}{|c|c|c|c|c|c|c|}
\hline $\mathbf{1 3}$ & 0.20 & 38.30 & 0 & 0.2 & 0 & 38.1 \\
\hline $\mathbf{1 4}$ & 0.70 & 40.40 & 0 & 0.7 & 0 & 39.7 \\
\hline $\mathbf{1 5}$ & 0.20 & 44.60 & 0 & 0.2 & 0 & 44.4 \\
\hline $\mathbf{1 6}$ & 0.00 & 50.40 & 0 & 0 & 0 & 50.4 \\
\hline $\mathbf{1 7}$ & 0.00 & 51.50 & 0 & 0 & 0 & 51.4 \\
\hline $\mathbf{1 8}$ & 0.00 & 50.50 & 0 & 0 & 0 & 50.4 \\
\hline $\mathbf{1 9}$ & 1.50 & 48.50 & 0 & 1.5 & 0 & 47.1 \\
\hline $\mathbf{2 0}$ & 1.00 & 46.60 & 0 & 1 & 0 & 45.6 \\
\hline $\mathbf{2 1}$ & 0.20 & 44.20 & 0 & 0.2 & 0 & 44 \\
\hline $\mathbf{2 2}$ & 6.00 & 39.50 & 0 & 6 & 0 & 33.5 \\
\hline $\mathbf{2 3}$ & 7.70 & 30.80 & 0 & 7.7 & 0 & 23.1 \\
\hline $\mathbf{2 4}$ & 62.50 & 27.20 & 35.3 & 27.2 & 0 & 0 \\
\hline $\mathbf{2 5}$ & 83.10 & 33.00 & 85.4 & 33 & 0 & 0 \\
\hline $\mathbf{2 6}$ & 35.70 & 39.10 & 83.9 & 37.3 & 0 & 1.9 \\
\hline $\mathbf{2 7}$ & 63.20 & 36.50 & 110.6 & 36.5 & 0 & 0 \\
\hline $\mathbf{2 8}$ & 79.70 & 38.20 & 152.2 & 38.2 & 0 & 0 \\
\hline $\mathbf{2 9}$ & 94.20 & 38.40 & 187 & 38.4 & 21 & 0 \\
\hline $\mathbf{3 0}$ & 80.60 & 37.70 & 187 & 37.7 & 42.8 & 0 \\
\hline $\mathbf{3 1}$ & 76.30 & 35.00 & 187 & 35 & 41.3 & 0 \\
\hline $\mathbf{3 2}$ & 66.40 & 33.10 & 187 & 33.1 & 33.3 & 0 \\
\hline $\mathbf{3 3}$ & 43.40 & 30.10 & 187 & 30.1 & 13.3 & 0 \\
\hline $\mathbf{3 4}$ & 27.60 & 26.30 & 187 & 26.3 & 1.4 & 0 \\
\hline $\mathbf{3 5}$ & 34.30 & 21.40 & 187 & 21.4 & 13 & 0 \\
\hline $\mathbf{3 6}$ & 35.10 & 19.90 & 187 & 19.9 & 15.3 & 0 \\
\hline $\mathbf{3 7}$ & 47.40 & 28.80 & 187 & 28.8 & 18.6 & 0 \\
\hline $\mathbf{3 8}$ & 43.20 & 34.00 & 187 & 34 & 9.2 & 0 \\
\hline $\mathbf{3 9}$ & 25.70 & 38.80 & 174.4 & 38.3 & 0 & 0.4 \\
\hline $\mathbf{4 0}$ & 16.60 & 44.20 & 150.4 & 40.6 & 0 & 3.6 \\
\hline $\mathbf{4 1}$ & 3.50 & 46.60 & 119.3 & 34.6 & 0 & 12 \\
\hline $\mathbf{4 2}$ & 2.10 & 47.30 & 93.5 & 27.8 & 0 & 19.5 \\
\hline $\mathbf{4 3}$ & 3.30 & 45.50 & 74.5 & 22.3 & 0 & 23.2 \\
\hline $\mathbf{4 4}$ & 0.00 & 42.90 & 59.2 & 15.3 & 0 & 27.6 \\
\hline $\mathbf{4 5}$ & 6.70 & 38.60 & 49.9 & 16 & 0 & 22.6 \\
\hline $\mathbf{4 6}$ & 1.20 & 32.50 & 42.2 & 8.9 & 0 & 23.6 \\
\hline $\mathbf{4 7}$ & 1.60 & 27.50 & 36.7 & 7 & 0 & 20.5 \\
\hline $\mathbf{4 8}$ & 0.10 & 23.80 & 32.3 & 4.4 & 0 & 19.4 \\
\hline $\mathbf{4 9}$ & 0.00 & 26.60 & 28 & 4.3 & 0 & 22.3 \\
\hline $\mathbf{5 0}$ & 0.00 & 28.80 & 24 & 4 & 0 & 24.8 \\
\hline $\mathbf{5 1}$ & 0.00 & 32.60 & 20.2 & 3.9 & 0 & 28.8 \\
\hline $\mathbf{5 2}$ & 0.00 & 33.70 & 16.8 & 3.3 & 0 & 30.3 \\
\hline & & & & & & \\
\hline $\mathbf{2 0}$ & & & 0 & 0 & 0 \\
\hline
\end{tabular}


Table.7 Crop coefficients for groundnut, cotton and wheat crops at different crop growth stage

\begin{tabular}{|c|c|c|c|c|c|c|c|c|c|c|c|c|}
\hline \multirow[t]{2}{*}{ stages } & Crop & \multirow[t]{2}{*}{ week } & \multirow[t]{2}{*}{$\mathbf{k}_{\mathrm{c}}$} & \multirow{2}{*}{$\begin{array}{l}\text { crop } \\
\text { Groundn } \\
\text { ut(bunch) }\end{array}$} & \multirow[t]{2}{*}{ week } & \multirow[t]{2}{*}{$\mathbf{k}_{\mathrm{c}}$} & \multirow{2}{*}{$\begin{array}{l}\text { Crop } \\
\text { Groundnut(s } \\
\text { preading) }\end{array}$} & \multirow[t]{2}{*}{ week } & \multirow[t]{2}{*}{$\mathbf{k}_{\mathrm{c}}$} & \multirow{2}{*}{$\begin{array}{l}\text { crop } \\
\text { wheat }\end{array}$} & \multirow[t]{2}{*}{ week } & \multirow[t]{2}{*}{$\mathbf{k}_{\mathrm{c}}$} \\
\hline & Cotton & & & & & & & & & & & \\
\hline \multirow[t]{4}{*}{ initial } & 27 & & .50 & 27 & & .40 & 27 & & .40 & 46 & & .40 \\
\hline & 29 & & .50 & 29 & & .40 & 29 & & .40 & 47 & & .40 \\
\hline & 30 & & .50 & & & & 30 & & .40 & 48 & & .40 \\
\hline & 31 & & .50 & & & & & & & & & \\
\hline \multirow[t]{4}{*}{ Deve. } & 33 & & .35 & 30 & & .47 & 31 & & .60 & 49 & & .80 \\
\hline & 36 & & .50 & 33 & & .76 & 33 & & .80 & 50 & & 1.5 \\
\hline & 38 & & .70 & & & & 34 & & 1.1 & 51 & & 1.5 \\
\hline & 39 & & .80 & & & & & & & 1 & & 1.5 \\
\hline \multirow[t]{5}{*}{ Mid } & 40 & & 1.1 & 34 & & 1.07 & 35 & & 1.15 & 2 & & 1.5 \\
\hline & 42 & & 1.2 & 35 & & 1.15 & 37 & & 1.15 & 3 & & 1.2 \\
\hline & 46 & & 1.2 & 36 & & 1.15 & 38 & & 1.15 & 4 & & 1.2 \\
\hline & 47 & & 1.2 & 37 & & 1.15 & & & & 5 & & 1.2 \\
\hline & & & & & & & & & & 6 & & .90 \\
\hline \multirow[t]{4}{*}{ Late } & 48 & & 1.05 & 38 & & 1.17 & 39 & & 1.05 & 7 & & .80 \\
\hline & 50 & & .90 & 39 & & .98 & 42 & & .80 & 8 & & .50 \\
\hline & 52 & & .80 & 40 & & .60 & 44 & & .60 & 9 & & .42 \\
\hline & 3 & & .60 & & & & & & & 10 & & .42 \\
\hline
\end{tabular}

Table.8 Crop water requirement of kharif cotton

\begin{tabular}{|c|c|c|c|c|c|}
\hline \multicolumn{6}{|c|}{ Crop water requirement of kharif cotton (mm/period) } \\
\hline $\begin{array}{c}\text { Sowing } \\
\text { week }\end{array}$ & $\begin{array}{c}\text { Stage I } \\
\text { (Initial stage) } \\
\text { (35 days) }\end{array}$ & $\begin{array}{l}\text { Stage II } \\
\text { (Growth } \\
\text { stage) } \\
\text { (55 days) }\end{array}$ & $\begin{array}{c}\text { Stage II } \\
\text { (Mid-season } \\
\text { stage) } \\
(60 \text { days })\end{array}$ & $\begin{array}{c}\text { Stage IV } \\
\text { (Late season } \\
\text { stage) } \\
\text { (45 days) }\end{array}$ & $\begin{array}{c}\text { Total } \\
\text { growing } \\
\text { season } \\
\text { (200 days) }\end{array}$ \\
\hline 27 & 47.61 & 174.91 & 361.89 & 234.01 & 818.42 \\
\hline
\end{tabular}

Table.9 Crop water requirement of kharif groundnut (bunch)

\begin{tabular}{|c|c|c|c|c|c|}
\hline \multicolumn{5}{|c|}{ Crop water requirement of kharif groundnut } \\
\hline $\begin{array}{c}\text { Sowing } \\
\text { week }\end{array}$ & $\begin{array}{c}\text { Stage I } \\
\text { (From sowing } \\
\text { to flowering } \\
\text { initiation }) \\
\text { (21 days) }\end{array}$ & $\begin{array}{c}\text { Stage II } \\
\text { (Flowering } \\
\text { initiation to } \\
\text { full } \\
\text { pegging) } \\
\text { (28 days) }\end{array}$ & $\begin{array}{c}\text { Stage II } \\
\text { (Full pegging } \\
\text { to pod } \\
\text { development) } \\
\text { (28 days) }\end{array}$ & $\begin{array}{c}\text { Stage IV } \\
\text { (Pod } \\
\text { development } \\
\text { to pod } \\
\text { maturity) } \\
\text { (21 days) }\end{array}$ & $\begin{array}{c}\text { Total } \\
\text { growing } \\
\text { season } \\
\text { (98 days) }\end{array}$ \\
\hline $\mathbf{2 7}$ & 40.88 & 79.85 & 135.69 & 82.21 & 338.63 \\
\hline
\end{tabular}


Table.10 Crop water requirement of kharif groundnut (spreading)

\begin{tabular}{|c|c|c|c|c|c|}
\hline \multicolumn{6}{|c|}{ Crop water requirement of kharif groundnut (spreading)(mm/period) } \\
\hline $\begin{array}{c}\text { Sowing } \\
\text { week }\end{array}$ & $\begin{array}{c}\text { Stage I } \\
\text { (From sowing to } \\
\text { flowering } \\
\text { initiation ) } \\
\text { (25 days) }\end{array}$ & $\begin{array}{c}\text { Stage II } \\
\text { (Flowering } \\
\text { initiation to full } \\
\text { pegging) } \\
\text { (30 days) }\end{array}$ & $\begin{array}{c}\text { Stage II } \\
\text { (Full pegging } \\
\text { to pod } \\
\text { development) } \\
\text { (35 days) }\end{array}$ & $\begin{array}{c}\text { Stage IV } \\
\text { (Pod } \\
\text { development to } \\
\text { pod maturity) } \\
\text { (30 days) }\end{array}$ & $\begin{array}{l}\text { Total growing } \\
\text { season } \\
\text { (120 days) }\end{array}$ \\
\hline 27 & 41.91 & 63.81 & 180.35 & 128.01 & 414.08 \\
\hline
\end{tabular}

Table.11 Crop water requirement of rabi wheat

\begin{tabular}{|c|c|c|c|c|c|}
\hline \multicolumn{7}{|c|}{ Crop water requirement of rabi wheat(mm/period) } \\
\hline $\begin{array}{c}\text { Sowing } \\
\text { week }\end{array}$ & $\begin{array}{c}\text { Stage I } \\
\text { (Initial stage) } \\
\text { (21 days) }\end{array}$ & $\begin{array}{c}\text { Stage II } \\
\text { (Growth stage) } \\
\text { (34 days) }\end{array}$ & $\begin{array}{c}\text { Stage II } \\
\text { (Mid-season stage) } \\
\text { (35 days) }\end{array}$ & $\begin{array}{c}\text { Stage IV } \\
\text { (Late season } \\
\text { stage) } \\
\text { (30 days) }\end{array}$ & $\begin{array}{c}\text { Total growing } \\
\text { season } \\
(120 \text { days) }\end{array}$ \\
\hline $\mathbf{4 6}$ & 33.51 & 172.38 & 290.17 & 85.20 & 581.28 \\
\hline
\end{tabular}

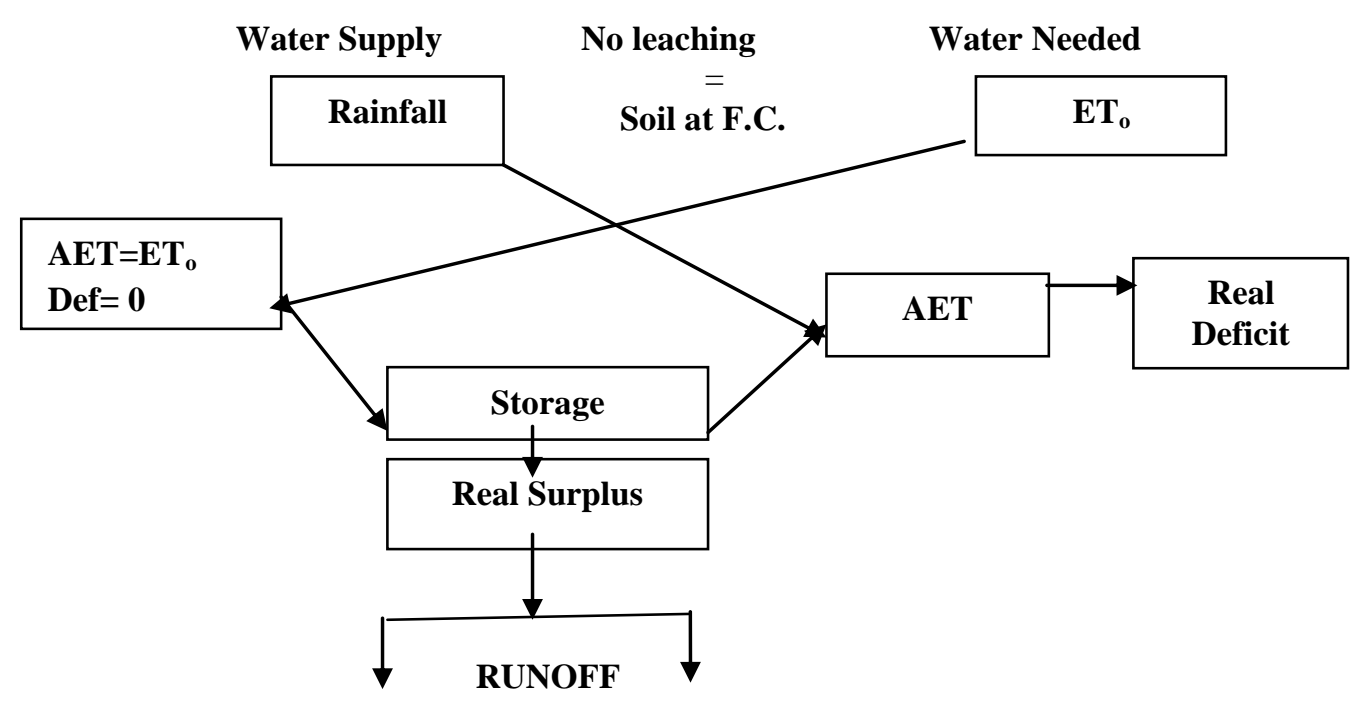

Fig.1 Generalized flow diagram of the climatic water balance

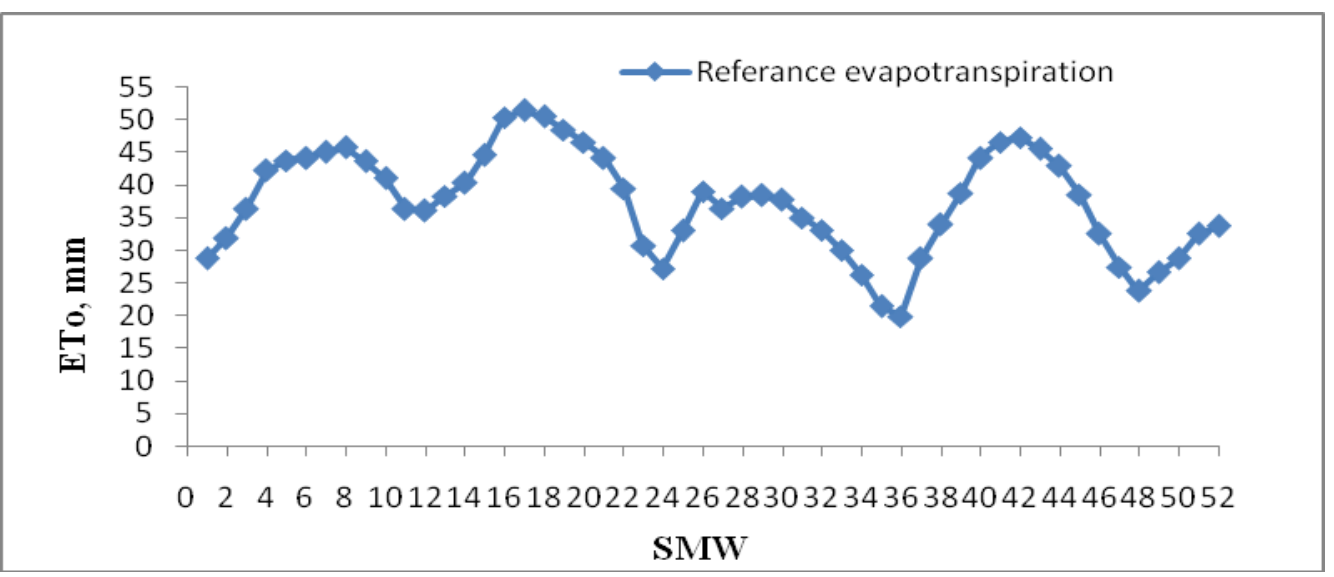

Fig.2 Variation of weekly reference evapotranspiration at Junagadh (1981-2017) 


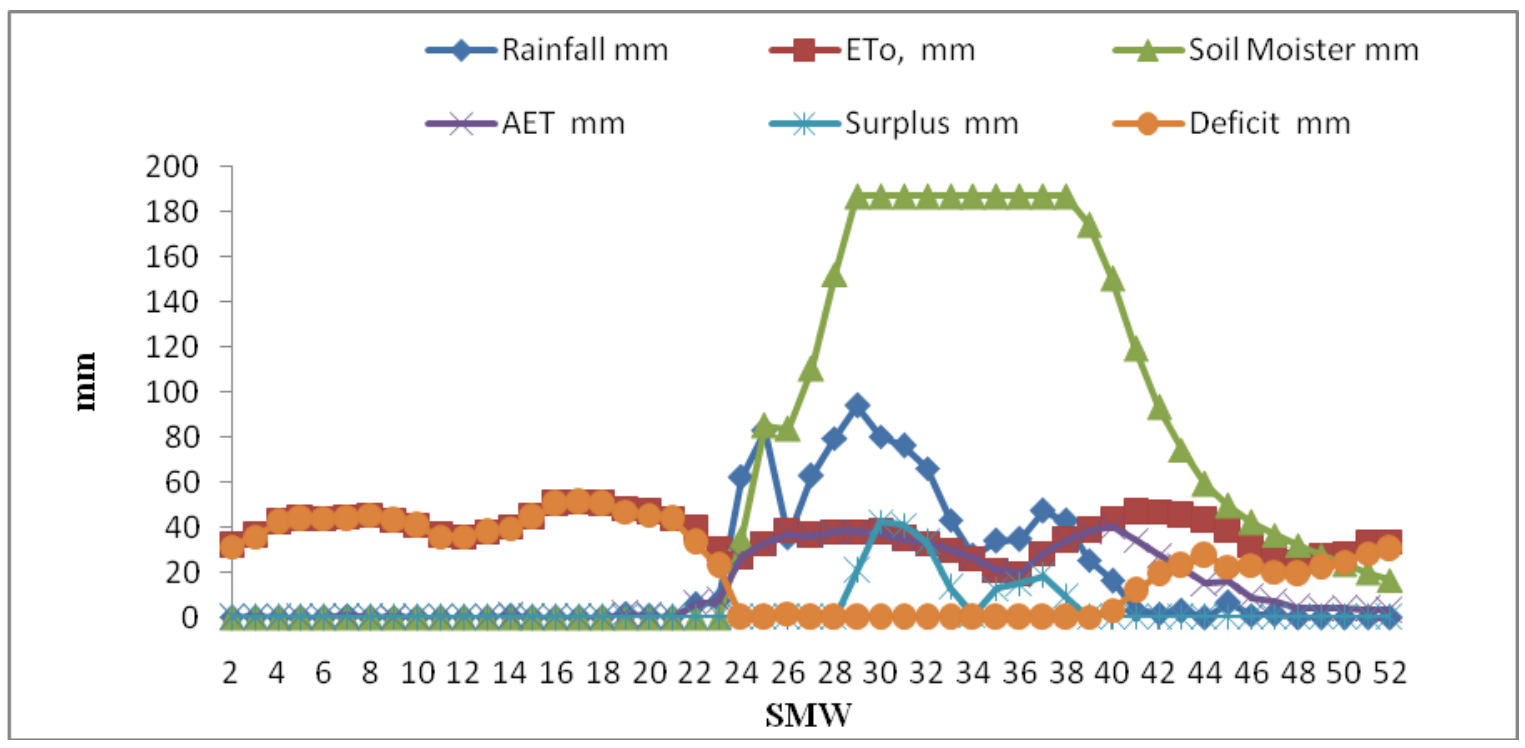

Fig.3 Weekly Water balance at Junagadh (1981 to 2017)

1. More than $25 \mathrm{~mm}$ assured rainfall is expected after $26^{\text {th }}$ SMW whereas 10 to 23 $\mathrm{mm}$ assured rainfall is expected in 24-26 SMW at $75 \%$ probability. Therefore land preparation can be carried out in 24-26 SMW. 2. Gamma distribution and Gumbel maximum distribution is found to be best fit distribution for SMW weeks 24, 26, 28, 29, 32, 42 SMW and $40^{\text {th }}, 41^{\text {st }}$ SMW respectively. In remaining SMW, Generalized Extreme value distribution is found to be best fit distribution. 3) Water balance study revealed that surplus water during $29^{\text {th }}$ to $38^{\text {th }}$ SMW may be harvested and used for supplemental irrigation. Also water balance study reveals that there is deficit of water after $38^{\text {th }}$ SMW. So supplementary irrigation should be applied to crops at the critical crop growth stages.

\section{Application of research}

Weekly rainfall analysis by Probability distribution method and thornthwaite method calculated surplus and deficit water for crop playing in Junagadh district of Gujarat

\section{Abbreviation and symbol}

cm Centimeter m meter

$\%$ Percentage

$\&$ And

mm millimeter

- Degree

${ }^{\circ} \mathrm{C}$ Degree Celsius

P Rainfall

I Irrigation

ET Evapotranspiration

$\mathrm{R}$ Surface runoff

D Deep drainage

${ }^{\Delta S}$ Change in soil moisture

AET Actual evapotranspiration

AWC Moisture storage capacity of soil

$P$ Precipitation

$\mathrm{ET}_{\mathrm{o}}$ Reference evapotranspiration

PET Potential evapotranspiration

ACC Accumulation water in system

FC Field capacity

PWP Permanent wilting point

$\mathrm{P}_{\mathrm{b}} \quad$ Bulk density

CV Coefficient of variation

SMW Standard Metrological Week

$\mathrm{ET}_{\mathrm{c}}$ Crop water requirement

$\mathrm{K}_{\mathrm{c}}$ crop coefficient

\section{Acknowledgement}

Author thankful to Department of Soil and 
Water Conservation Engineering, Polytechnic in Agricultural Engineering, Targhadia, 360023, Junagadh Agricultural University, Junagadh, 362001, Gujarat, India

\section{References}

Alam, A. M. J., Rahman, M. S. andSadaat, A. H. M.(2014). Markov Chain Analysis of weekly rainfall data for predicting agricultural drought. Computational intelligence techniques in earth and environmental sciences, 109-128.

Alam, N. M., Ranjan, R., Adhikary, P. P., Kumar, A., Jana, C., Panwar, S., Mishra, P. K. and Sharma, N. K. (2016). Statistical modelling of weekly rainfall data for crop planning in Bundelkhand region of central India. Indian Journal of Soil Conservation, 44( 3): 336-342.

Allen, R. G., Pereira, L. S., Raes, D. amd Smith, M. (1998). Crop evapotranspiration guidelines for computing crop water requirement. Irrigation and Drain, Paper No. FAO 56, Rome, Italy.

Ashkar, F. and Mahdi, S. (2003). Comparison of two fitting methods for the log-logistic distribution. Water Resources Research, 39(8): 12-17.

Chakravarti, Laha and Ray, (1967) Handbook Method of Applied Statistics. John Wiley and Sons, (1):11-27.

Chandulal, (2018) Fenugreek(Trigonellafoenumgraecum L.) Crop response under drip irrigation system. M.Tech(Soil and Water Conservation Engineering) Thesis. Junagadh Agricultural University, Junagadh.

Clarke, R. T. (2003). Comparison of estimators of linear time trend in Weibull-distributed low flows. Water Resources Research, 39(7): 1180-1191.

Doorenbos, J. and Pruitt, W. O. (1975). Guidelines for predicting crop water requirements, Irrigation and Drainage Paper 24, FAO of the United Nations, Rome. 179 pp.

Dwivedi, D. K., Sharma, G. R. and Patel, D. V. (2017) Identification of Rainfall Probability Distribution for Junagadh. International Journal of Agricultural Science and Research,7(2):521-528.

Mehta, R. and Pandey, V. (2016) Crop water requirement $\left(\mathrm{ET}_{\mathrm{c}}\right)$ of different crops of middle Gujarat. Journal of Agrometeorology, 18 (1): 83-87.

Quiring, S. M. and Papakryiakou, T. N. (2003). An evaluation of agricultural drought indices for the Canadian Prairies. Agricultural Forest Meteorological. 118: 49-62.

Ray, C. R, Senapati, P. C. and Lal, R. (1987). Investigation of drought from rainfall data at Gopalpur (Orissa). Indian Journal Soil Conservation , 15(1): 15-19.En

Sharma, H. C., Chauhan, H. S. and Ram, S. (1975). Probability analysis of rainfall for crop planning. Journal of Agricultural Engineering, 14: 87-94.

Sharma, M. A. and Singh, J. B. (2010). Use of Probability Distribution in Rainfall Analysis. New York Science Journal, 3(9):40-49.

Stephens, M. A. (1974). EDF Statistics for Goodness of Fit and Some Comparisons, Journal of the American Statistical Association, 69:730-737.

Thornthwaite, C. W. and Mather, J. R. (1955). The Water Balance Laboratory of Climatology: Centerton, New Jersey.

\section{How to cite this article:}

Pappu Kumar Paswan, G. R. Sharma, Abhishek Pratap Singh and Ojha. M. D. 2020. Weekly Rainfall Analysis for Crop Planning in Junagadh District of Gujarat, India. Int.J.Curr.Microbiol.App.Sci. 9(05): 223-240. doi: https://doi.org/10.20546/ijcmas.2020.905.026 